\title{
KEDUDUKAN KEJAKSAAN SEBAGAI PELAKSANA KEKUASAAN NEGARA DI BIDANG PENUNTUTAN DALAM STRUKTUR KETATANEGARAAN INDONESIA
}

\author{
DIAN ROSITA, S.KOM., SH
}

\begin{abstract}
ABSTRAK
Selama ini pengaturan kedudukan Kejaksaan tidak diatur secara tegas dalam Undang-Undang Dasar Negara Republik Indonesia Tahun 1945 hanya disebut secara eksplisit dalam Pasal 24 ayat (3) UUD NRI Tahun 1945 yang menyatakan, "Badan-badan lain yang fungsinya berkaitan dengan kekuasaan kehakiman diatur dalan undang-undang." Pasal 2 ayat (1) Undang -Undang Kejaksaan No. 16 Tahun 2004 tentang Kejaksaan menyebutkan bahwa Kejaksaan adalan lembaga pemerintah yang melaksanakan kekuasaan Negara dibidang penuntutan serta kewenangan lain yang berdasarkan undang-undang. Sehingga secara kelembagaan berada di bawah kekuasaan eksekutif namun dalam menjalankan tugas dan fungsinya merupakan bagian dari kekuasaan yudikatif yang menjadikan ketidakjelasan kedudukan Kejaksaan dalam struktur ketatanegaraan Indonesia. Penelitian ini menggunakan metode yuridis normatif dengan spesifikasi penelitian yang bersifat preskriptis analitis. Jenis data yang digunakan dalam penelitian ini adalah data sekunder, yaitu data yang diperoleh melalui bahan hukum primer, sekunder dan tersier. Simpulan yang diperoleh dari hasil penelitian ini adalah kedudukan Kejaksaan yang secara kelembagaan berada di bawah kekuasaan eksekutif dan secara kewenangan dalam melaksanakan tugas dan fungsinya termasuk bagian dari kekuasaan yudikatif menyebabkan Kejaksaan rawan terhadap intervensi kekuasaan lainnya dalam melaksanakan tugas dan fungsinya sebagai pelaksana kekuasaan negara di bidang penuntutan. Serta untuk mewujudkan kekuasaan penuntutan yang independen maka perlu untuk melakukan reposisi kedudukan Kejaksaan Republik Indonesia
\end{abstract}

Kata Kunci: Kejaksaan, Kedudukan, Penuntutan 
THE POSITION OF PRESECUTOR AS THE EXECUTOR OF STATE POWER IN THE FIELD OF PRESECUTION IN INDONESIAN STATE ADMINISTRATION

\author{
DIAN ROSITA, S.KOM., SH
}

\begin{abstract}
So far, the regulation of the Public Prosecutor's Office is not expressly stipulated in the 1945 Constitution of the State of the Republic of Indonesia. It is only mentioned explicitly in Article 24 Paragraph (3) of the 1945 Constitution of the Republic of Indonesia which states, "Other bodies whose functions relate to the judicial authority are regulated in legislation" Article 2 paragraph (1) of the Prosecutor's Law No. 16 of 2004 on the Prosecutor's Office. It states that the Attorney is a government institution that exercises state power in the field of prosecution and other authorities based on the law. So that institutionally, it is under the executive authority but in carrying out its duties and functions it is part of the judicial power that makes the ambiguity of the position of the Prosecutor in the structure of the state administration. This research used normative juridical method with analytic prescriptive research specification. The type of data used in this study is secondary data, data were secondary data which gained from primary, secondary and tertiary legal materials. The conclusion derived from the results of this study is the position of the Attorney which is institutionally under the authority of the executive. Further, its authority in carrying out its duties and functions includes part of the judicial power, it causes the Attorney is prone to other power intervention in carrying out its duties and functions as the executor of state power in the field of prosecution. To realize the power of independent prosecution, it is necessary to reposition the position of the Prosecutor of the Republic of Indonesia.
\end{abstract}

Keywords: Procurator, Position, Prosecution 


\section{A. Pendahuluan}

$\mathrm{Di}$ Indonesia, kekuasaan yudikatif lazim disebut dengan kekuasaan kehakiman. Menurut Penjelasan Pasal 24 ayat (1) Undang - Undang Dasar 1945, Kekuasaan Kehakiman adalah kekuasaan yang merdeka, artinya terlepas dari pengaruh kekuasaan pemerintah. Pada masa konstitusi RIS (1950 1959), kedudukan Kejaksaan memang masuk dalam struktur Departemen Kehakiman. Wewenang Jaksa Agung tertera pada Pasal 156 ayat (2), Pasal 157 ayat (1) dan Pasal 15 ayat (3) Konstitusi RIS. Setelah Dekrit Presiden 5 Juli 1959 ( 5 Juli 1959 - 11 Maret 1960 ) terjadi perubahan status Kejaksaan dari lembaga non departemen di bawah Departemen Kehakiman menjadi lembaga yang berdiri sendiri. Hal ini diperkuat dengan adanya Keputusan
Presiden Nomor 204 Tahun 1960 tentang Pembentukan Departemen Kejaksaan yang dikeluarkan oleh Presiden Soekarno pada tanggal 22 Juli 1960 yang secara tegas membentuk Departemen Kejaksaan di bawah pimpinan menteri / Jaksa Agung.

Keputusan Presiden tersebut diikuti dengan lahirnya Undang -Undang Nomor 15 Tahun 1961 tentang Pokok Pokok Kejaksaan Republik Indonesia (selanjutnya disebut sebagai UU Kejaksaan Tahun 1961). Latar belakang dari pembentukan undang - undang tersebut adalah memberikan ketentuan yang jelas tentang struktur organisasi Kejaksaan serta kekuasaannya, terutama sebagai perlengkapan negara dalam bidang pertahanan dan keamanan. Dalam konsiderans UU Kejaksaan Tahun 1961 disebutkan bahwa Kejaksaan sebagai alat negara penegak 
hukum dalam menyelesaikan revolusi, sebagai alat revolusi yang bertugas sebagai penuntut umum. Meskipun dalam Pasal 1 ayat (1) UndangUndang Kejaksaan Tahun 1961 dinyatakan bahwa Kejaksaan bukanlah "alat pemerintah" tetapi "alat negara", namun dalam Pasal 5 ayat (1) undang-undang yang sama dinyatakan bahwa "penyelenggaraan tugas Departemen Kejaksaan dilakukan oleh Menteri dan susunan organisasi

Departemen Kejaksaan diatur dengan Keputusan Presiden."

Sejalan dengan perkembangan kebutuhan hukum dalam masyarakat dan kehidupan ketatanegaraan, UU Kejaksaan Tahun 1961 dianggap tidak sesuai lagi dengan pertumbuhan dan perkembangan hukum, maka kemudian diganti dengan Undang-Undang Nomor 5
Tahun 1991 tentang Kejaksaan Republik Indonesia (selanjutnya disebut sebagai UU Kejaksaan Tahun 1991), yang mencabut UU Kejaksaan Tahun 1961. Pembaharuan UU Kejaksaan Tahun 1991 dimaksudkan untuk menetapkan kedudukan dan peran Kejaksaan agar lebih mampu dan berwibawa dalam melaksanakan tugas dan wewenangnya sebagai lembaga pemerintahan yang melaksanakan kekuasaan negara di bidang penuntutan, sebagaimana disebutkan dalam Pasal 2 ayat (1) UU Kejaksaan Tahun 1991 serta dijelaskan dalam penjelasan pasal tersebut yang menyatakan bahwa Kejaksaan adalah satusatunya lembaga pemerintahan pelaksana kekuasaan negara yang mempunyai tugas dan wewenang di dalam bidang penuntutan dalam penegakan hukum dan keadilan di lingkungan peradilan umum. 
Semua lembaga

peradilan yang ada di Indonesia identik disebut dengan Kekuasaan Kehakiman.

Menurut Pasal 24 ayat (1) UUD NRI Tahun 1945, Kekuasaan Kehakiman merupakan "kekuasaan yang merdeka untuk menyelenggarakan peradilan guna menegakkan hukum dan keadilan." Dari ketentuan Pasal tersebut tidak ditemukan adanya batasan pengertian mengenai kekuasaan kehakiman. Ketentuan mengenai "badan badan lain yang fungsinya berkaitan dengan kekuasaan kehakiman diatur dalam undang-undang" diatur dalam Pasal 38 ayat (3) Undang Undang Republik Indonesia Nomor 48 Tahun 2009 tentang Kekuasaan Kehakiman (selanjutnya disebut sebagai Kekuasaan Kehakiman Tahun 2009). Penjelasan Pasal 38 ayat (3) UU Kekuasaan
Kehakiman Tahun 2009 tersebut di atas, yang dimaksud "badan-badan lain" antara lain Kepolisian, Kejaksaan, Advokad dan Lembaga Pemasyarakatan.

Dari penjelasan Pasal tersebut diketahui bahwa kedudukan Kejaksaan merupakan bagian dari organ kehakiman, namun berdasarkan Pasal 2 ayat (1) UU Kejaksaan Tahun 1991 sebagaimana telah dijelaskan di atas, Kejaksaan adalah satusatunya lembaga pemerintah yang melaksanakan kekuasaan negara di bidang penuntutan.

\section{B. Perumusan Masalah}

1. Bagaimana kedudukan Kejaksaan sebagai pelaksana kekuasaan negara di bidang penuntutan dalam struktur ketatanegaraan Indonesia? 
2. Bagaimana upaya yang dilakukan

untuk

mewujudkan independensi

Kejaksaan

sebagai

pelaksana

kekuasaan

negara

di bidang

penuntutan dalam struktur

ketatanegaraan Indonesia?

\section{Tinjauan Pustaka}

1. Sistem Ketatanegaraan Indonesia

Dengan diproklamirkan

Kemerdekaan

Bangsa

Indonesia pada tanggal 17

Agustus 1945 berarti bahwa

mulai pada saat itu telah berdiri negara baru, yaitu Negara Republik Indonesia. Merdeka berarti bahwa bangsa Indonesia telah siap untuk mengambil sikap menentukan nasib bangsa dan tanah air dalam segala bidang. Dalam bidang hukum berarti bahwa Bangsa Indonesia telah memutuskan dengan tatanan hukum Hindia Belanda maupun pemerintahan Jepang. Dengan kata lain, Bangsa Indonesia telah mendirikan tatanan hukum baru yang ditentukan dan akan dilaksankan sendiri oleh Bangsa Indonesia.

Proklamasi

Kemerdekaan Indonesia merupakan perwujudan formal daripada satu pergerakan revolusi bangsa Indonesia untuk menyatakan baik kepada diri sendiri maupun dunia internasional bahwa mulai pada saat itu telah mengambil sikap untuk menentukan bangsa dan nasib tanah air di dalam tangan bangsa sendiri, yaitu mendirikan Negara sendiri termasuk tata hukum dan tata negaranya. ${ }^{1}$

Perkembangan

ketatanegaraan Indonesia sejak Proklamasi dengan UUD 1945 dan Pancasila sebagai Falsafah 
Negara tidak berjalan dengan mulus karena Belanda selalu ingin menancapkan kembali kekuasaannya. Untuk menyelesaikan konflik Inonesia dan Belanda, maka pada tanggal 23 Agustus - 2 November 1949 oleh Perserikatan Bangsa-Bangsa (PBB) diadakan Konferensi antara Negara Republik Indonesia dan Nederland yang dikenal dengan nama Konferensi Meja Bundar (KMB). Dalam konferensi tersebut dihadiri oleh delegasi Republik Indonesia dan delegasi bijeenkomst voor federal overleg (BFO) serta delegasi Nederland dan Komisi Perserikatan Bangsa-Bangsa untuk Indonesia yang kemudian menghasilkan tiga kesepakatan yaitu, mendirikan negara Indonesia Serikat, penyerahan kedaulatan kepada Republik Indonesia Serikat (RIS), dan mendirikan UNI antara RIS dengan kerajaan Belanda $^{2}$

Dengan berdirinya negara Republik Indonesia Serikat, wilayah Republik Indonesia masih tetap berada di samping negara federal Republik Indonesia Serikat. Sesuai dengan ketentuan Pasal 2 Konstitusi RIS, Republik Indonesia diakui sebagai salah satu negara bagian dalam wilayah Republik Indonesia Serikat yaitu mencakup wilayah yang disebut dalam Perjanjian Renville. $^{3}$ Bentuk negara federal RIS ini tidak bertahan lama. Mula-mula tiga wilayah negara bagian yaitu Negara Republik Indonesia, Negara Indonesia Timur dan Negara Sumatera Timur menggabungkan diri menjadi 
satu wilayah Republik Indonesia. $^{4}$

Pada tanggal 17 Agustus

1950 Indonesia resmi kebali

menjadi Negara Kesatuan RI namun masih sering terjadi pemberontakan separatisme sehingga pada 5 Juli 1959 Presiden Soekarno mengeluarkan Dekrit Presiden yang salah satu isinya adalah memberlakukan kembali UUD 1945 sebagai Undang-Undang Dasar Negara Republik Indonesia. Sejak Dekrit Presiden 5 Juli 1959, sistem pemerintahan Negara yang dianut kembali berdasar pada Undang-Undang Dasar 1945, yakni berdasar pada sistem pemerintahan Presidensial.

Masa setelah Dekrit Presiden 5 Juli 1959 dikenal dengan Masa Orde Lama/Demokrasi Terpimpin (5 Juli 1959 - 11 Maret 1966).
Pada masa Demokrasi Terpimpin ini banyak sekali terjadi penyimpanganpenyimpangan atau penyelewengan-

penyelewengan terhadap Pancasila dan UUD 1945 yang dilakukan Pemimpin dalam hal ini oleh Presiden sehingga banyak menimbulkan kekacauan sosial budaya dan tidak stabilnya politik dan hukum ketatanegaraan Indonesia. Puncaknya adalah terjadinya perisiwa Gerakan 30 September 1965 yang dilakukan oleh PKI. Untuk mengatasi hal tersebut, kemudian Presiden Soekarno mengeluarkan Surat Perintah kepada Letnan Jenderal Soeharto yaitu Surat Perintah $11 \quad$ Maret 1966 (SUPERSEMAR), untuk mengambil segala tindakan dalam menjamin keamanan dan ketentraman masyarakat 
serta stabilitas jalannya pemerintahan.

\begin{tabular}{lrr}
\multicolumn{2}{r}{ Bulan Maret } & 1967, \\
MPRS mengadakan & sidang \\
istimewa dalam & rangka
\end{tabular} mengukuhkan pengunduran diri Presiden Soekarno sekaligus mengangkat Jenderal Soeharto sebagai pejabat presiden $\mathrm{RI}$. Jenderal

Soeharto menanamkan

era kepemimpinanya sebagai orde baru atau Demokrasi Pancasila (11 Maret 1966 - 21 Mei 1998). Penyelenggaraan

pemerintahan negara dengan sistem pemerintahan Presidensial dengan berdasar pada Demokrasi Pancasila. Selama berkuasa kurang lebih 32 tahun Presiden Soeharto cenderung melakukan praktik Korupsi Kolusi Nepotisme (KKN), pada tahun 1998 terjadi gejolak yang sangat luar biasa dari masyarakat, yang menuntut mundurnya Soeharto. Gerakan tersebut disebut gerakan reformasi. akhirnya pada tanggal 21 Mei 1998 Soeharto menyatakan berhenti sebagai Presiden. Lengsernya Soeharto dikenal dengan masa Orde Reformasi (21 Mei 1998 sampai sekarang), penyelenggaraan pemerintahan masih tetap berlandaskan Undang-Undang Dasar 1945, yakni menganut sistem pemerintahan presidensial. Namun, dalam pelaksanaannya dilakukan secara kristis (reformis) artinya peraturan perundangan yang tidak berjiwa reformis diubah/diganti.

\section{Kejaksaan}

Republik Indonesia

Kejaksaan Republik Indonesia terus mengalami berbagai perkembangan dan dinamika secara terus menerus sesuai dengan kurun waktu dan perubahan sistem pemerintahan. Pada masa konstitusi RIS (1950 - 1959), kedudukan Kejaksaan masuk 
dalam struktur Departemen Kehakiman. Wewenang Jaksa Agung tertera pada Pasal 156 ayat (2), Pasal 157 ayat (1) dan Pasal 15 ayat (3) Konstitusi RIS. Setelah Dekrit Presiden 5 Juli 1959 (5 Juli 1959 - 11 Maret 1960) terjadi perubahan status Kejaksaan dari lembaga non departemen di bawah Departemen Kehakiman menjadi lembaga yang berdiri sendiri. Hal ini diperkuat dengan adanya Keputusan Presiden Nomor 204 Tahun 1960 tentang Pembentukan Departemen Kejaksaan yang dikeluarkan oleh Presiden Soekarno pada tanggal 22 Juli 1960 yang secara tegas membentuk Departemen Kejaksaan di bawah pimpinan menteri / Jaksa Agung. Keputusan Presiden tersebut diikuti dengan lahirnya Undang -Undang Nomor 15 Tahun 1961 tentang Pokok - Pokok Kejaksaan Republik Indonesia.
Undang -Undang Nomor 15 Tahun 1961 tentang Pokok Pokok Kejaksaan Republik Indonesia ini menegaskan Kejaksaan sebagai alat negara penegak hukum yang bertugas sebagai penuntut umum ${ }^{5}$, penyelenggaraan tugas departemen Kejaksaan dilakukan Menteri / Jaksa Agung dan susunan organisasi yang diatur oleh Keputusan Presiden. ${ }^{6}$

Kejaksaan sebagai pengendali proses perkara (Dominus Litis), mempunyai kedudukan sentral dalam penegakan hukum, karena hanya institusi Kejaksaan yang dapat menentukan apakah suatu kasus dapat diajukan ke Pengadilan atau tidak berdasarkan alat bukti yang sah menurut Hukum Acara Pidana. ${ }^{7}$

\footnotetext{
${ }^{5}$ Undang - Undang Nomor 15 Tahun 1961 tentang Pokok - Pokok Kejaksaan Republik Indonesia, Pasal 1

${ }_{7}^{6}$ Ibid. Pasal 5

Marwan Effendy, Kejaksaan RI , Posisi dan Fungsinya ... Op.cit, hlm.105.
} 
Disamping

sebagai

penyandang Dominus Litis,

Kejaksaan juga merupakan

satu-satunya instansi

pelaksana putusan pidana (executive ambtenaar). ${ }^{8}$ Karena

itulah, Undang-Undang

Kejaksaan yang baru ini

dipandang lebih kuat dalam

menetapkan kedudukan dan

peran Kejaksaan RI sebagai

lembaga negara pemerintah

yang melaksanakan kekuasaan

negara di bidang penuntutan.

\section{Sistem Penuntutan}

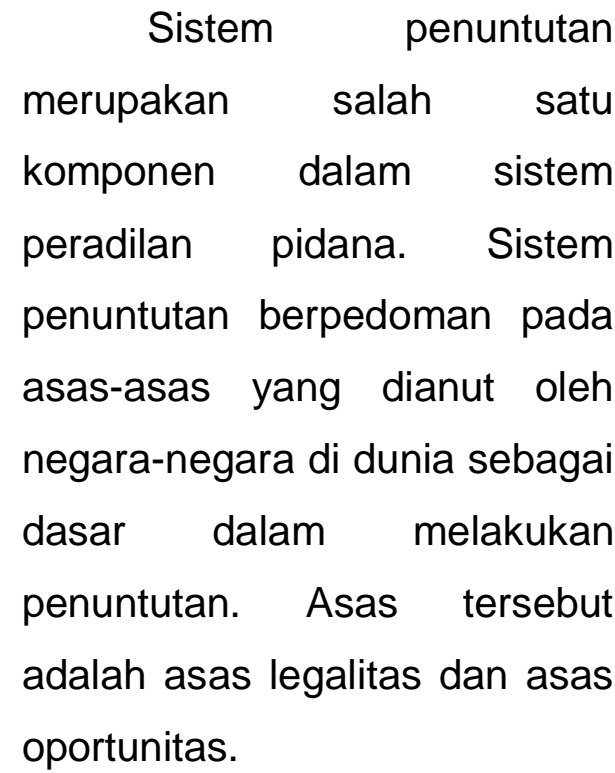

Penuntutan dilakukan

oleh penuntut umum, dan penuntut umum adalah Jaksa yang diberi wewenang oleh undang-undang ini untuk melakukan penuntutan dan melaksanakan penetapan hakim.

\section{Kekuasaan Negara}

Negara Indonesia berdasarkan pada hukum. Hal tersebut ditegaskan dalam Pasal 1 ayat (3) UndangUndang Dasar Negara Republik Tahun 1945. Konsekuensi dari ketentuan tersebut adalah bahwa setiap sikap, perilaku, pikiran dan kebijakan pemerintah negara dan penduduknya harus didasarkan pada hukum. Dengan ketentuan yang demikian dimaksudkan untuk mencegah terjadinya kesewenangwenangan dan arogansi kekuasaan. 
Lasswell $^{9}$ berpendapat bahwa kekuasaan adalah partisipasi dalam membuat keputusan yang penting. Kekusaan dapat diperoleh dari kedudukan dan dari kepercayaan.

Kolaborasi antara hukum dan kekuasaan ditegaskan oleh Mac Iver dengan merumuskan kekuasaan sebagai kemampuan untuk mengendalikan tingkah laku orang lain baik secara langsung dengan memberi perintah maupun secara tidak langsung dengan menggunakan alat dan cara yang tersedia. Dengan kata lain dapat diartikan sebagai kemampuan Negara untuk mengendalikan tingkah laku masyarakat dengan menggunakan hukum dan peraturan yang berlaku.

\footnotetext{
${ }^{9}$ Anggina Mutiara Hanum, "Teori Kekuasaan Negara Pola Relasi Kekuasaan Di Indonesia Pada Masa Orde Baru Hingga Era Reformasi", (Pasca Sarjana Departemen IImu Politik Fakultas IImu Politik IImu Sosial Universitas Indonesia, 2014), hlm. 7.
}

\section{Metode Penelitian}

1. Metode Pendekatan

Metode pendekatan yang peneliti gunakan adalah pendekatan perundangundangan (statute approach) ini dilakukan dengan cara menelaah semua undangundang dan regulasi yang berkaitan dengan kekuasaan Kehakiman dan kedudukan Kejaksaan sebagai pelaksana kekuasaan negara di bidang penuntutan

\section{Spesifikasi Penelitian}

Penelitian ini lebih mengarah kepada spesifikasi penelitian yang preskriptis analitis, dimana Penulis memberikan saran atau rekomendasi mengenai kedudukan Kejaksaan sebagai pelaksana kekuasaan negara di bidang penuntutan, bagaimana upaya untuk mewujudkan independensi Kejaksaan sebagai pelaksana kekuasaan 
penuntutan dalam struktur ketatanegaraan Indonesia.

\section{Jenis Data}

Jenis data yang digunakan dalam penelitian ini adalah data sekunder, yaitu data yang diperoleh melalui bahan hukum primer, sekunder dan tersier.

\section{Metode Pengumpulan Data}

Metode pengumpulan data yang Penulis gunakan dalam penelitian tentang Kedudukan Kejaksaan Sebagai Pelaksana Kekuasaan Negara di Bidang Penuntutan Dalam Struktur Ketatanegaraan Indonesia ini adalah penelitian kepustakaan (literature research) dan juga melalui penelitian melalui internet (internet research). Data kepustakaan ini Penulis peroleh dari peraturan perundang-undangan, bukubuku, dokumen resmi, publikasi dan hasil penelitian yang berkaitan dengan permasalahan dalam penelitian ini. Sedangkan penelitian melalui internet ini Penulis lakukan dengan menggunakan search enggine (mesin pencari) ${ }^{10}$ untuk menemukan bahan-bahan hukum baik primer maupun sekunder.

\section{Metode Analisis Data}

Analisis normatif kualitiatif Penulis gunakan untuk menganalisis permasalahan dalam penelitian tentang "Kedudukan Kejaksaan Sebagai Pelaksana Kekuasaan Negara di Bidang Penuntutan Dalam Struktur Ketatanegaraan Indonesia." Dalam mendeskripsikannya, Penulis membuat ulasan serta telaah kritis mengenai konsep-konsep dan teori-teori yang

\footnotetext{
${ }^{10}$ Seacrh enggine (mesin pencari) adalah progran yang mengijinkan seseorang untuk mencari web pada website yang memberikan informasi yang diinginkan.
} 
dikemukakan oleh para ahli terhadap komparasi perundang-undangan dalam kaitannya terhadap struktur ketatanegaraan Indonesia untuk menggiring opini yang dapat dijadikan rujukan untuk menyelesaikan permasalahan hukum yang menjadi objek kajian dalam penelitian.

\section{E. Hasil dan Pembahasan}

\section{Kemandirian Kejaksaan sebagai pelaksana kekuasaan kehakiman}

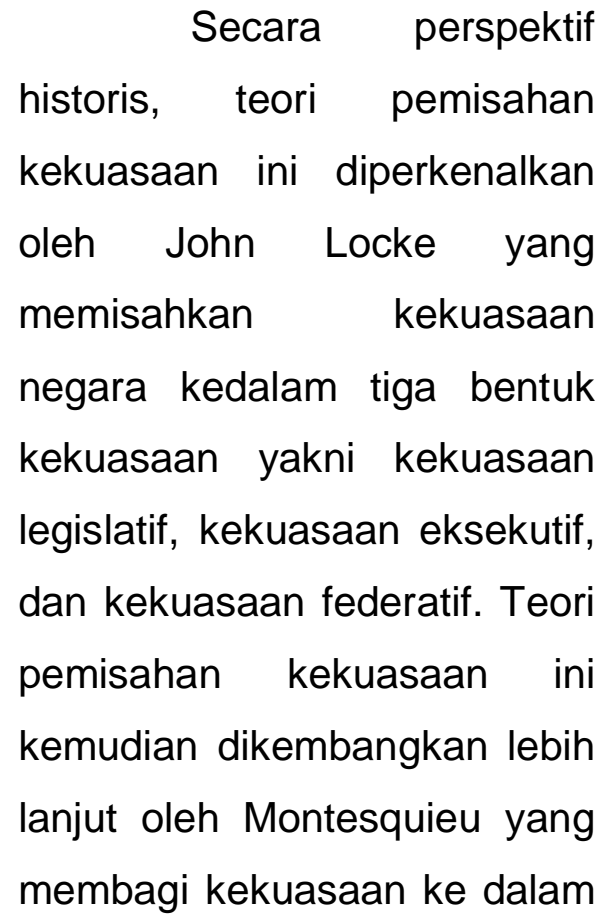

tiga bentuk kekuasaan, yakni kekuasaan legislatif, kekuasaan eksekutif dan kekuasaan yudikatif.

$\mathrm{Di}$ Indonesia, kekuasaan eksekutif adalah kekuasaan untuk menjalankan undang-undang dan menyelenggarakan pemerintah negara. Kekuasaan ini dipegang oleh Presiden sebagaimana ditegaskan dalam Pasal 4 ayat (1) UUD NRI Tahun 1945 yang menyatakan bahwa Presiden Republik Indonesia memegang kekuasaan pemerintahan menurut Undang-undang Dasar. Kekuasaan legislatif yaitu kekuasaan untuk membentuk undang-undang. Kekuasaan ini dipegang oleh Dewan Perwakilan Rakyat (DPR) sebagaimana ditegaskan dalam pasal 20 ayat (1) UUD NRI Tahun 1945 yang menyatakan bahwa Dewan Perwakilan Rakyat 
memegang kekuasaan

membentuk undang-undang.

Kekuasaan yudikatif lazim

disebut dengan kekuasaan

kehakiman yakni kekuasaan

untuk menyelenggarakan

peradilan guna menegakkan

hukum dan keadilan.

Kekuasaan

Kehakiman dalam struktur ketatanegaraan Indonesia diatur dalam Bab IX Pasal 24, Pasal 24 A, B, C dan Pasal 25 Undang-Undang Dasar Negara Republik Indonesia Tahun 1945 (UUD NRI Tahun 1945). Kejaksaan dalam struktur ketatanegaraan Indonesia ditempatkan sebagai lembaga kekuasaan eksekutif. Secara ekplisit lembaga Kejaksaan memang tidak disebutkan dalam UUD NRI Tahun 1945 namun sebagai lembaga penegak hukum, Kejaksaan merupakan bagian yang tidak dapat dipisahkan dari kekuasaan kehakiman.

Kejaksaan termasuk salah satu badan yang fungsinya berkaitan dengan kekuasaan kehakiman menurut Undang-Undang Dasar Negara Republik Indonesia Tahun 1945. Pernyataan tersebut terdapat dalam konsideran menimbang huruf b UU Kejaksaan Tahun 2004. ${ }^{11}$ Pengertian kekuasaan kehakiman yang dimaksud di sini dipertegas dalam Pasal 1 Ayat 1 UU Kehakiman Tahun $2009^{12}$ yang berbunyi; "Kekuasaan kehakiman adalah kekuasaan negara yang merdeka untuk menyelenggarakan peradilan guna menegakkan hukum dan keadilan berdasarkan Pancasila dan UndangUndang Dasar Negara Republik Indonesia Tahun 1945 demi terselenggaranya

\footnotetext{
11 Undang-Undang Nomor 16 Tahun 2004 Tentang Kejaksaan Republik Indonesia

${ }_{12}$ Undang - Undang Nomor 48 Tahun 2009 Tentang Kekuasaan Kehakiman
} 
negara hukum Republik Indonesia.

Kemandirian

Kejaksaan sebagai lembaga yang melaksanakan kekuasaan kehakiman bidang penuntutan ini dapat dibagi menjadi 2 (dua) aspek, yaitu: 13 Mandiri secara Institusional (kelembagaan) Mandiri secara lembaga berarti bahwa Kejaksaan itu ditempatkan dalam posisi yang independen secara kelembagaan. Kejaksaan memang semestinya lebih baik ditempatkan secara mandiri secara kelembagaan dan lepas dari kekuasaan manapun.

(2) Mandiri secara fungsional. Mandiri secara fungsional berarti bahwa Jaksa itu

13 Royzal A Nur Rahman, "Kedudukan Kejaksaan Republik Indonesia Menurut Undang-Undang Dasar 1945”, (Fakultas Hukum Universitas Lampung, 2017), hlm. 8. bisa bebas dan merdeka dalam menjalankan tugasnya untuk menuntut ataukah tidak menuntut.

Dari dua aspek kemandirian tersebut diatas, bukanlah masalah jika secara kelembagaan Kejaksaan tidak Independent, sepanjang secara fungsional Kejaksaan bisa bebas menjalankan fungsinya tanpa intervensi. Permasalahannya disini adalah jika Kejaksaan secara fungsional tidak independent, karena tujuan penuntutan dalam hukum acara pidana adalah untuk mendapat penetapan dari penuntut umum tentang adanya alasan cukup untuk menuntut seorang terdakwa di muka hakim.

Hakim dan Jaksa pada tahun 1945-1959 berada di bawah kementerian kehakiman, namun demikian baik Hakim maupun Jaksa sunguh-sungguh 
"independent". Setelah tahun 1959 tepatnya setelah adanya Keputusan Presiden Nomor 204 Tahun 1960 tentang Pembentukan Departemen Kejaksaan yang dikeluarkan dari Departemen Kehakiman oleh Presiden Soekarno pada tanggal 22 Juli 1960 dan diikuti dengan lahirnya Undang Undang Nomor 15 Tahun 1961 tentang Pokok - Pokok Kejaksaan Republik Indonesia, Kejaksaan memang "mandiri", mempunyai badan sendiri dan terlepas dari Departemen Kehakiman, namun independensinya telah hilang karena Jaksa Agung bukan lagi Jaksa Agung dalam Mahkamah Agung tetapi menteri atau anggota kabinet sebagai pembantu Presiden yang setiap saat dapat diganti oleh Presiden.

Jika Jaksa tidak independent dalam penuntutan, maka mustahil hakim akan dapat independent karena putusannya tergantung dari dakwaan Jaksa. Banyak kalangan yang menganggap mustahil Kejaksaan dalam menjalankan fungsi, tugas dan wewenangnya terlepas dari pengaruh kekuasaan lainnya karena Kedudukannya secara kelembagaan berada di bawah kekuasaan eksekutif.

2. Kemandirian Kejaksaan sebagai subsistem dalam Sistem Peradilan Pidana Sistem Peradilan Pidana (criminal justice system) adalah sistem dalam suatu masyarakat untuk menanggulangi masalah kejahatan, yaitu untuk mengendalikan kejahatan agar berada dalam batas-batas toleransi masyarakat. ${ }^{14}$ Tolib Effendi menjelaskan bahwa Sistem Peradilan Pidana

14 Mardono Reksodiputro, Hak asasi Manusia Dalam Sistem Peradilan Pidana, Cetakan Ketujuh (Jakarta: Pusat Pelayanan Keadilan dan Pengabdian Hukum Universutas Indonesia, 2007), hlm. 84 
memiliki dua tujuan besar, yaitu untuk melindungi masyarakat dan menegakan hukum.

Terkait dengan tujuan dari Sistem Peradilan Pidana, Barda Nawawi Arief $^{15}$ mengimplementasikan 4 (empat) sub sistem kekuasaan, yakni kekuasaan penyidikan, kekuasaan penuntutan, kekuasan mengadili/menjatukan pidana dan kekuasaan eksekusi/pelaksanaan pidana. Sebagaimana diketahui bahwa dalam sistem peradilan pidana Indonesia, kekuasaan penyidikan dimiliki oleh Kepolisian, kekuasaan penuntutan dimiliki oleh Kejaksaan, dan kekusaan mengadili/menjatuhkan pidana dimiliki oleh Pengadilan. boleh dipegang sendiri oleh mereka yang menerapkannya.

15 Barda Nawawi Arief, Bunga Rampai Op.Cit. hlm. 23
Kejaksaan dalam sub sistem peradilan pidana melaksanakan kekuasaan negara dibidang penuntutan. Pasal 1 angka 1 UU Kejaksaan Tahun 2004 menyebutkan bahwa:

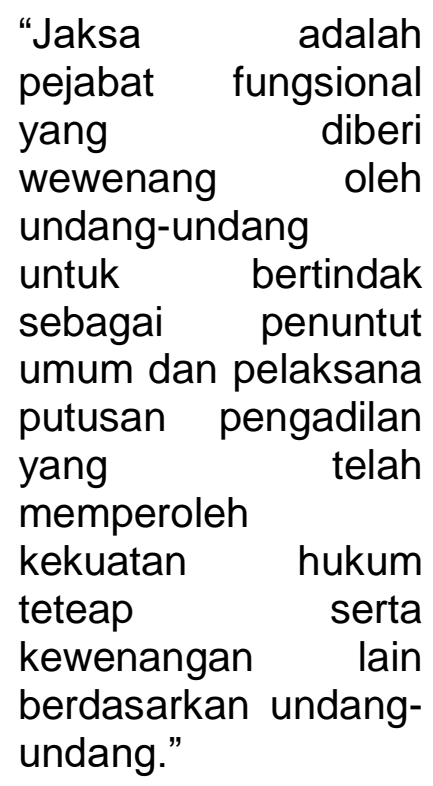

Pasal 1 angka 3 UU Kejaksaan Tahun 2004 menyebutkan bahwa:

"Penuntutan adalah tindakan penutut umum untuk melimpahkan perkara ke Pengadilan Negeri yang berwenang dalam hal dan menurut cara yang 
diatr dalam Hukum Acara Pidana dengan permintaan supaya diperiksa dan diputus oleh hakim di sidang pengadilan."

Berdasarkan kedua pasal tersebut di atas, dalam melakukan penuntutan, Jaksa bertindak untuk dan atas nama negara sehingga harus bisa menampung kepentingan masyarakat, negara dan korban kejahatan agar bisa dicapai keadilan. Kedudukan Kejaksaan dalam peradilan pidana bersifat menentukan karena merupakan jembatan yang menghubungkan antara tahap penyidikan dengan tahap pemeriksaan di pengadilan.

Banyak fakta yang menunjukkan dalam penanganan sebuah kasus Kejaksaan sangat rentan diintervensi oleh kekuasaan eksekutif. Agar dapat menjaga independensinya, Kejaksaan dalam sistem peradilan pidana yang menjalankan fungsi kekuasaan kehakiman harus terpisah dari kekuasaan lain. Oleh karenya perlu dibuat legitimasi yang kuat dan dinyatakan dengan tegas dalam konstitusi dan diturunkan dalam peraturan perundang-undangan yang relevan. Dengan demikian jika ada pihak-pihak tertentu yang melakukan intervensi terhadap tugas dan wewenang Kejaksaan, maka Kejaksaan mempunyai landasan yang kuat untuk menolak.

\section{Reposisi Kedudukan} Kejaksaan dalam Struktur Ketatanegaraan Indonesia Tidaklah dipungkiri bahwa perdebatan panjang mengenai eksistensi kewenangan penuntutan oleh Kejaksaan dan posisinya dalam struktur ketatanegaraan 


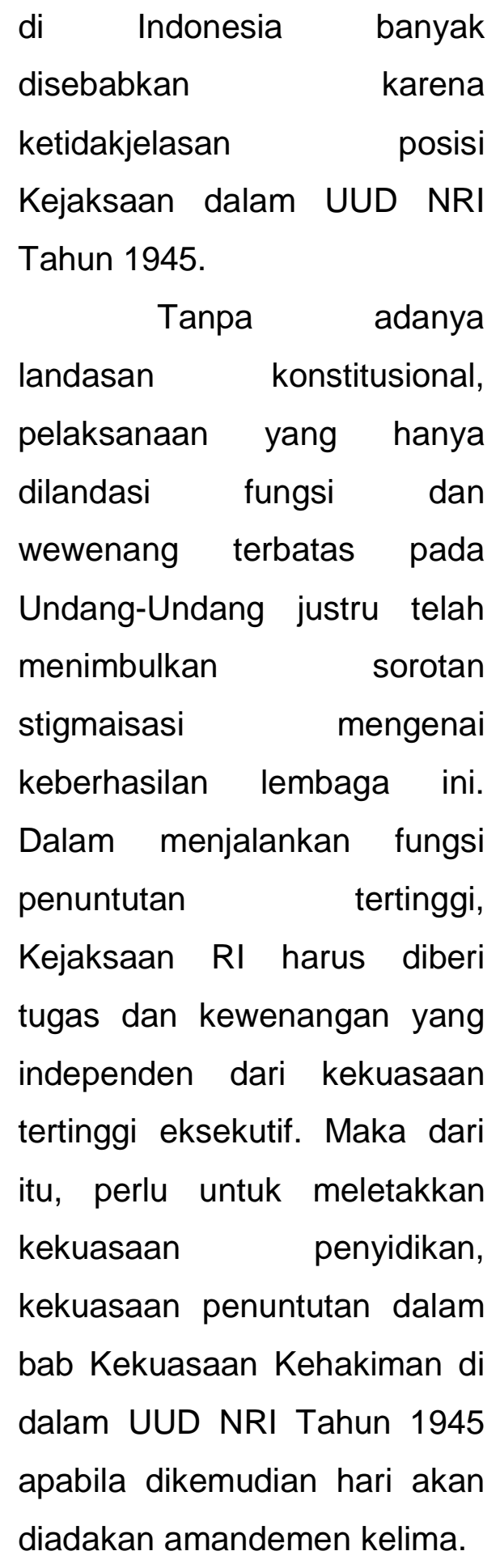

Akan tetapi
mengubah UUD 1945 memang
bukanlah hal yang mudah,
prosesnya membutuhkan
waktu yang relative lama,
apalagi bila para elite politik
memiliki sudut pandang dan
kepentingan yang berbeda,
kesepakatan dan keputusan
politik akan sulit diambil. Di sisi
lain peningkatan kinerja
Kejaksaan harus segera
dilakukan. Tindakan yang
realitis dan dapat dilakukan
dengan segera yaitu dengan
merevisi UU Kejaksaan.

\section{F. Penutup}

\section{Simpulan}

1. Kedudukan Kejaksaan yang secara kelembagaan berada di bawah kekuasaan eksekutif dan secara kewenangan dalam melaksanakan tugas dan fungsinya termasuk bagian dari kekuasaan 
yudikatif menyebabkan

Kejaksaan rawan

terhadap intervensi

kekuasaan lainnya

dalam melaksanakan

kekuasaan di bidang

penuntutan terkait

perannya sebagai

lembaga pemerintah.

2. Untuk mewujudkan

kekuasaan penuntutan

yang independen maka

perlu untuk melakukan

reposisi kedudukan

Kejaksaan Republik

Indonesia. Reposisi

yang dimaksud dalam

hal ini dalah

menempatkan

Kejaksaan Republik

Indonesia sebagai

bagian dari kekuasaan

kehakiman yang murni

dan terbebas dari

intervensi kekuasaan

politik dengan cara

mencantumkan

Kejaksaan Republik
Indonesia secara

eksplisit kedalam pasal

di Undang-Undang

Dasar Negara Republik Indonesia Tahun 1945 atau dengan merevisi Undang-Undang Nomor 16 Tahun 2004 Tentang Kejaksaan.

\section{Saran}

1. Kedudukan dan fungsi Kejaksan RI dalam bingkai Negara hukum Pancasila adalah sangat tepat apabila Kejaksaan RI sebaiknya menjadi suatu "badan Negara" yang mandiri dan independen dalam melaksanakan kekuasan Negara di bidang penuntutan dan kewenangan lain sebagaimana yang ditetapkan oleh undangundang artinya profesionalitas dan kemandirian kejaksaan 
dalam melakukan tugas

penuntutan harus

ditempatkan sebagai

sesuatu yang sama

sekali tidak boleh

diintervensi.

2. Harus

disadari

Kejaksaan merupakan bagian integral dari kekuasaan kehakiman. Independensi kekuasaan kehakiman akan sangat dipengaruhi oleh independennya lembaga-lembaga lain yang terlibat dalam sistem peradilan pidana terpadu sehingga Kejaksaan harus dikeluarkan dalam struktur kekuasaan eksekutif.

3. Kejaksaan hendaknya direposisi sebagai bagian dari kekuasaan kehakiman. Selain itu juga sebagai lembaga pelaksana kekuasaan yudisial penting untuk mengatur kedudukan Kejaksaan secara eksplisit dalam UUD 1945.

\section{DAFTAR PUSTAKA}

\section{Buku-buku}

Asshiddiqie, J. 2014. Konstitusi dan Konstitusionalisme Indonesia. Jakarta: Sinar Grafika.

Effendy, M. 2005. Kejaksaan RI, Posisi dan Fungsinya dari Perspektif Hukum. Jakarta: PT Gramedia Pustaka Utama.

Joeniarto. 2001. Sejarah Ketatanegaraan Republik Indonesia. Jakarta: Sinar Grafika Offset.

Reksodiputro, M. 2007. Hak Asasi Manusia dalam Sistem Peradilan Pidana. Cetakan Ketujuh. Jakarta: Pusat Pelayanan Keadilan dan Pengabdian Hukum Universutas Indonesia. 
Jurnal Hukum, Laporan

Penelitian, Artikel

Hanum, A. M. 2014. Teori Kekuasaan Negara Pola Relasi Kekuasaan di Indonesia Pada Masa Orde Baru Hingga Era Reformasi. Jakarta: Pasca Sarjana Departemen IImu Politik FISIP UI.

Rahman, R. A. 2017. Kedudukan Kejaksaan Republik Indonesia Menurut UndangUndang Dasar 1945. Lampung: Fakultas Hukum Universitas Lampung.

\section{Peraturan Perundang-undangan}

Undang-Undang Dasar Negara

Republik Indonesia

Tahun 1945

Undang Undang Nomor 15 Tahun 1961 tentang Ketentuan-ketentuan Pokok Kejaksaan Republik Indonesia;
Undang-Undang Nomor 14

Tahun 1970 tentang Pokok-Pokok

Kekuasaan

Kehakiman;

Undang-Undang Nomor 8

Tahun 1981 tentang

Hukum Acara Pidana;

Undang-Undanng Nomor 35

Tahun 1999 tentang

Perubahan Undang-

Undang Nomor 14

Tahun 1970 tentang

Pokok-Pokok

Kekuasaan

Kehakiman;

Undang-Undang Nomor 4 Tahun 2004 Tentang Kekuasaan

Kehakiman;

Undang-Undang Nomor 16 Tahun 2004 tentang Kejaksaan Republik Indonesia;

Undang-Undang Nomor 48

Tahun 2009 tentang

Kekuasan Kehakiman; 